\title{
Assessment of the Economic Results of the Digital Transformation of the Client-Centric System of Sberbank of Russia
}

\author{
Vagif Musaev, Svetlana Khobotova, Irina Knyazeva, Nataliya Katunina, and Nataliya \\ Puzina* \\ Dostoevsky Omsk State University, 644077 Omsk, Russia
}

\begin{abstract}
The article analyzes the transformation of banking services based on the concepts of Bank 1.0, Bank 2.0, Bank 3.0, Bank 4.0. This transformation is largely associated with the formation of client-centric ecosystems that actively use artificial intelligence. Banks offer their clients convenient digital services based on platform and cloud technologies. The scientific novelty of the research is associated with the author's approach to assessing the economic results of Bank digitalization based on the construction of models of correlation and regression analysis and the method of accumulated excess profitability. The stated methodological approaches are tested on the example of Sberbank of Russia. It is concluded that the results obtained prove the positive impact of digitalization on the company's economic results due to the growth of customers, expansion of financial and non-financial digital companies and their products in the group of companies, reduction of offices and employees who performed banking operations in the traditional business model of banks.
\end{abstract}

\section{Introduction}

One of the most important trends in the development of the financial sector of the economy is digital transformation, which includes, first of all, consumer orientation, mobility and speed, and data. In her work, V. D. Markova notes that digital transformation (digitalization) of business is the process of turning a traditional organization into a digital company, in which both material and digital objects are present [1].

In recent years, the financial technology (FINTECH) industry has been actively developing. According to Ernst \& Young, the penetration rate of FINTECH services in the world in 2019 was $64 \%$, and consumer awareness of services in this industry was $96 \%$ of the total number of respondents [2]. For the financial sector of the economy, the development of FINTECH, as well as the trend of active business movement towards digital transformation, made it necessary to search for growth points.

The transformation of banking activity can be traced throughout the entire period of its development. In recent years, changes in the use of digital technologies have affected the

\footnotetext{
* Corresponding author: puzinanv@omsu.ru
} 
banking business in a special way, turning the country's largest banks into IT companies. American banker and innovator B. king is the founder of the modern concept of banking transformation. In the books "Bank 2.0 "and" Bank 3.0 " b. King argues that the era of classical banking services is over, and banks are actively creating a financial ecosystem to increase competition in the service delivery market. They enter into relationships with other banks and FINTECH companies [3].

In today's unstable global economic environment, the approach to applying innovations in the field of banking digitalization is changing. The most effective market players implement the principle of omnichannel in their business processes, which involves integrating their services into the daily life of the client to better meet their needs.

The chronology of transformation and characteristics of banking activity when changing four concepts are presented in Table 1.

Table 1. Transformation of banking services [3]

\begin{tabular}{|c|c|c|c|}
\hline $\begin{array}{l}\text { Concept } \\
\text { Period }\end{array}$ & Drivers & The Bank's services & Characteristics of banking activity \\
\hline Bank 1.0 & & & $\begin{array}{l}\text { The activity is based on classical } \\
\text { management principles. Provides standard } \\
\text { services for the population and companies, } \\
\text { providing their needs and acting as a } \\
\text { financial intermediary. }\end{array}$ \\
\hline $\begin{array}{c}\text { Bank 2.0 } \\
1970-80\end{array}$ & ATMS & $\begin{array}{l}\text { Active distribution of } \\
\text { ATMs in cities. The } \\
\text { provision of banking } \\
\text { services gets a new look } \\
\text { (a car instead of a person). }\end{array}$ & \multirow{2}{*}{$\begin{array}{l}\text { Active distribution of ATMs in cities. The } \\
\text { provision of banking services gets a new } \\
\text { look (a car instead of a person). Again, it is } \\
\text { based on classical management principles. } \\
\text { However, service delivery channels are } \\
\text { expanding (development of desktop and } \\
\text { mobile versions of banking applications). } \\
\text { The beginning of the digitalization stage is } \\
\text { taking place. }\end{array}$} \\
\hline $1990 \mathrm{~s}$ & The Internet & $\begin{array}{l}\text { Receiving Bank services } \\
\text { becomes possible by } \\
\text { means of remote } \\
\text { communication channels. }\end{array}$ & \\
\hline $\begin{array}{l}\text { Bank } 3.0 \text { The } \\
\text { beginning of } \\
\text { the XXI } \\
\text { century - } \\
\text { present } \\
\end{array}$ & $\begin{array}{l}\text { Smartphone } \\
\mathrm{s} \text {, Big Data, } \\
\text { Internet of } \\
\text { things, } \\
\text { Cloud Tech }\end{array}$ & $\begin{array}{l}\text { Banking apps appear. Due } \\
\text { to this, the need to visit } \\
\text { offices is reduced several } \\
\text { times. }\end{array}$ & $\begin{array}{l}\text { Banks are actively forming their own } \\
\text { ecosystem and partnerships. Efficiency is } \\
\text { also improved by automating services and } \\
\text { business processes. }\end{array}$ \\
\hline $\begin{array}{c}\text { Bank } 4.0 \\
\text { Coming decade }\end{array}$ & VR, AI & $\begin{array}{l}\text { There is a large-scale } \\
\text { implementation of } \\
\text { banking services in the } \\
\text { life of the end user by } \\
\text { spreading communication } \\
\text { channels with the client. } \\
\text { Use of augmented reality } \\
\text { in the provision of } \\
\text { banking services. }\end{array}$ & $\begin{array}{l}\text { The Bank becomes a tool that is actively } \\
\text { integrated into the life of the end user and } \\
\text { allows you to meet your needs "here and } \\
\text { now". The client can make an informed } \\
\text { financial decision using artificial } \\
\text { intelligence. }\end{array}$ \\
\hline
\end{tabular}

Today, the most important in the development of banking activities are Internet platforms that provide banking services "here and now". The key trend is that the client does not want to contact the Bank's office. They start their communication with a mobile app based on its convenience and simplicity. Banking in the transition to the "Bank 3.0" concept helps clients to meet their financial needs without contacting the branch directly. We can conclude that the Bank's task is to establish contact with the end user through its mobile app. As for the concept of "Bank 4.0", it is necessary to carry out a qualitative" transformation " in the development of banking services using artificial intelligence.

The processes of digitalization in the banking sector have not yet been sufficiently studied. Russian authors mostly refer to practical examples of digitalization in their works. For example, there are key innovations in the banking sector: security ("smart" authentication), Analytics (big data, personal financial assistants), digital technologies 
(online wallet, tactless payments, etc.), automation (robots in departments), gamification (games and quests for clients), P2P lending [4]. At the same time, theoretical and methodological aspects of evaluating the economic result of digitalization processes, including consumer services, usually lag behind practice.

In the literature, there are three options for implementing modern technologies in the banking business [5]:

1. Creating a new Bank (neobank, online Bank, direct Bank) - the Bank provides services only online through the website and mobile applications, there are no offices. An example is Tinkoff Bank.

2. Building a digital Bank from scratch with a classic Bank. Examples: Sberbank (Sbertech), VTB group (OTKRITIE Bank and its digital Department), Alfa-Bank (Alfa-lab).

3. Cooperation with FINTECH services or their purchase and integration into the existing banking business. At the same time, the main areas of cooperation are: improving the client interface, digitalizing processes, in-depth data-based Analytics, and expanding the product offer.

A key player in the Russian financial market is Sberbank of Russia, which has now switched to the third option of implementing digital technologies in its business. In 2017, Sberbank announced its development strategy, which included the development of a new technology platform. Today, such a platform - the digital ecosystem of Sberbank - includes more than 40 services of various types (Fig. 1).

Today, the digital ecosystem of SBER combines banking products and many nonbanking products and services, for example, SberMarket-a service for delivering products to your home and office, SberFood-a service for going to restaurants, and SBER solutions business process outsourcing services. In 2019, Sberbank started cooperation with two major Internet companies - Mail.Ru Group and Rambler, acquired a recruitment portal Rabota.ru, the company "center for speech technologies" and developed the internal areas of Sber Okko, SberDevices and SberLogistics. In 2020, Yandex.Market left the structure of Sberbank's digital ecosystem. Overall, Sberbank has strengthened its position in the transportation, food delivery, entertainment and media segments. The initiatives announced in Sberbank's development strategy may allow it to compete with global technology companies.

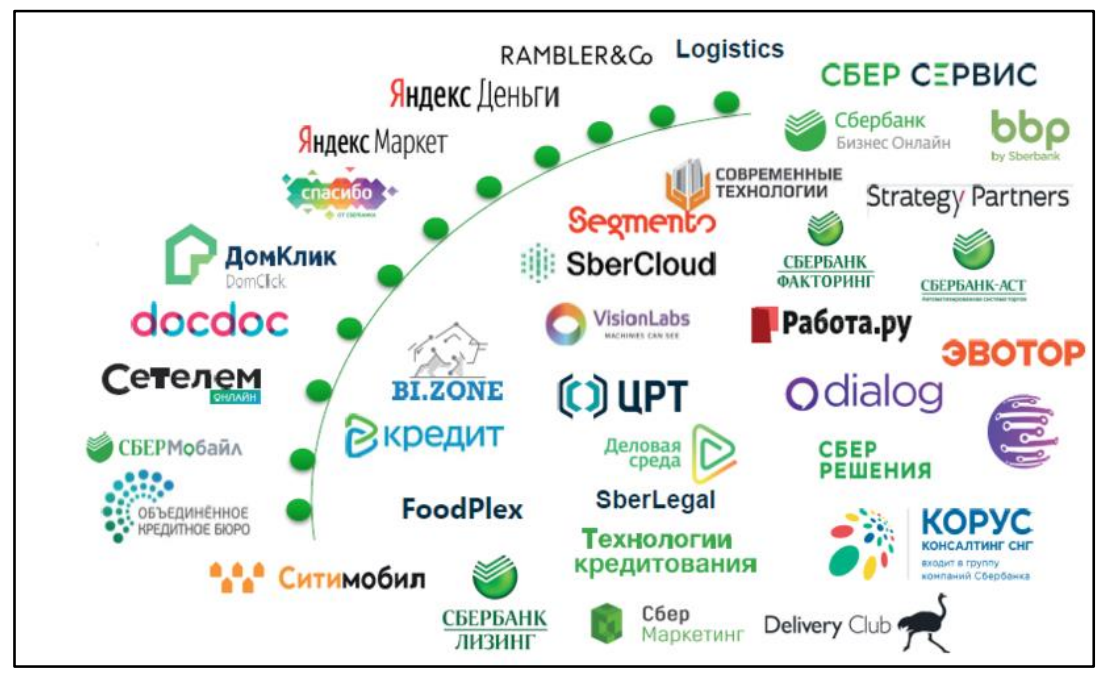

Fig. 1. Sberbank digital ecosystem, 2019 [6,7] 
In this regard, the purpose of this study is to propose and test methods for evaluating the results of the Bank's digital transformation using the example of Sberbank of Russia as part of the formation of a client-centered system.

\section{Methods and Types of the Digitalization's Analysis}

The digital transformation of Sberbank of Russia has been actively developing since 2017, and today digitalization processes are associated with the functioning of a digital platform, its own cloud structure, offering cloud solutions for customers, using big data and artificial intelligence for rapid and high-quality management decisions and transactions, the successful operation of the Sberbank Online mobile application, and others. To assess the impact of Sberbank of Russia's digital transformation on the group's performance, this study suggests using correlation and regression analysis to identify the impact and tightness of individual factors on the final result, as well as the accumulated excess yield method, which will help identify the reaction of the exchange market to business purchase transactions during the formation of the Sberbank of Russia ecosystem. The empirical base is the data of the annual reports of Sberbank of Russia, which are publicly available. We will highlight several stages of research based on the stated methods.

1. currently, online interaction opportunities allow you to create a new format of sales and customer relationships through financial ecosystems. Sberbank of Russia forms a client-centric ecosystem, i.e. the customer (retail customer or business) is placed at the center of the ecosystem, around which a set of services necessary for their life or work is formed. All this contributes to the fact that the Bank receives additional profit through digital transformation. First, from the influx of new customers. In 2019, the services of Sberbank of Russia were used by 96.2 million people. active retail customers $(+3$ million or $3.2 \%$ by 2018$)$ and 2.6 million active corporate clients $(+14 \%$ by 2018$)$ should also note Sberbank's leading positions in the mortgage markets $(54 \%)$, retail lending $(41 \%)$, and business lending (34\%). Second, from investments in elements of the ecosystem. Creating an open ecosystem based on digital products makes cooperation with the Bank convenient, reliable and profitable, and allows the Bank to reduce administrative costs (for example, for the maintenance of offices and staff $-12 \%$ reduction in the number of employees in 2019). And, third, as a result, improving the efficiency of the Bank, which is achieved, including due to the speed and quality of customer service using digital services. For example, in 2019 , at Sberbank of Russia, $40 \%$ of customer questions were resolved automatically by the chatbot, with 1,267 transactions worth 125 billion rubles. they were made using the "credit in 7 minutes" system, 21 thousand transactions with small business clients were made using the "credit in 3 minutes" system [8]. In the language of Finance, these results are reflected in terms of net interest income, net Commission income, and operating expenses.

To analyze the impact of the Bank's digital transformation, we will build a regression model of the dependence of the Bank's profit on the indicators that affect it:

$\Delta \mathrm{y}=\mathrm{a}_{0}+\mathrm{ax}_{1}+\mathrm{bx}_{2}+\mathrm{cx}_{3}+\mathrm{dx}_{4}+\mathrm{ex}_{5}(1)$

$\Delta y-$ increase in the Bank's net profit,

$\mathrm{a}_{0}, \mathrm{a}, \mathrm{b}, \mathrm{c}, \mathrm{d}, \mathrm{e}-$ weighting factor,

$\mathrm{x}_{1}$ - increase in net $\%$ of income,

$\mathrm{x}_{2}-$ the increase in net fee income,

$\mathrm{x}_{3}$ - increase in operating expenses,

$\mathrm{x}_{4}-$ increase in the number of employees,

$\mathrm{x}_{5}$ - increase in the number of offices.

This approach will allow you to identify the impact of each factor on the Bank's profit in a given model. 
2. The benefits of ecosystem Sberbank manifested through the nature of providing customers with different kinds of service, increase of customer loyalty, the prospects of your customer-oriented system and social insurance on the market. As a result, Sberbank increases user demand for financial products and expands its target segment. But no less significant is the assessment of the results of digitalization of Sberbank of Russia on the example of individual digital products. Today, the ability to remotely manage your accounts is a prerequisite for servicing in the Bank. Sberbank users can make transactions through the Sberbank online banking service system. The app's functionality for consumers is quite broad and includes the following features [9]:

- manage all accounts opened with the Bank;

- ability to pay for any services of legal entities and individuals (utility bills, fines, duties, etc.);

- transfer funds to a Deposit, top up a Deposit account, transfer money from an online account;

- add funds to e-wallets;

- perform repayment of third-party loans;

- perform money conversion;

- connect by selecting "auto payment", create payment templates;

- open debit and credit cards;

- view the geographical location of service offices and ATMs.

The introduction of the Sberbank Online mobile application led, on the one hand, to an increase in Commission income due to the convenience of using the application and reducing the cost of transactions by 2 times, and, on the other hand, it reduced the number of employees and offices that served this type of operations. This was reflected in an increase in the number of clients and their operations, as well as in a decrease in operating expenses.

Currently, the Sberbank Online mobile app is the Bank's most popular digital channel: its monthly audience grew by $30 \%$ in 2019 and exceeded 54 million people. At the same time, users still use the SMS service instead of the mobile app, and some users prefer the desktop version. To evaluate the effectiveness of the Sberbank Online mobile application, it is advisable to use correlation analysis to identify the impact on the Bank's profit of such factors as: investments, SMS service, mobile application, Internet banking, number of customers, number of employees, number of offices.

3. in a market economy, the market evaluates the results of business development. For public companies, this indicator can be the dynamics of their shares in the securities market. Therefore, it is proposed to study the economic effectiveness of the formation of elements of the Sberbank ecosystem when buying high-tech companies through the market reaction in terms of changes in the exchange quotations of its shares.

Based on stock exchange statistics, we will analyze the dynamics of Sberbank of Russia's shares against the background of the acquisition of a technology company and evaluate the effectiveness of this transaction using the accumulated excess yield (CAR) method. The change in stock prices should be compared with the change in the normal yield, which we will take the stock index of the Moscow exchange-IMOEX. For the observation window, take the segment $(-7 ;+7)$, where date 0 is the date of the event. Next, we calculate the daily yield of Sberbank shares and the IMOEX index using the formula:

$\mathrm{Rt}$ - daily profitability per day $\mathrm{t}$;

$$
R_{t}=\frac{P_{t}-P_{t-1}}{P_{t-1}} * 100 \%
$$

$\mathrm{Pt}$ - cost per day $\mathrm{t}$;

$\mathrm{Pt}-1$ - cost per day $\mathrm{t}-1$. 
Then we calculate the excess return on shares for each day of observation using the formula:

$$
A R_{i}=\left(C R_{i}-I R_{i}\right)
$$

$C R_{i}-$ daily profitability of Sberbank of Russia shares per day $\mathrm{i}$;

$I R_{i}$ - daily profit of the IMOEX index per day $i$.

Calculate the accumulated excess yield over the observation period, which acts as a criterion for the effectiveness of the transaction, using the formula:

$$
\mathrm{CAR}=\sum_{\mathrm{J}} \mathrm{AR}_{\mathrm{i}}
$$

$\mathrm{j}$ - number of days in "the observation window".

As an example, in our research, we will evaluate Sberbank's deal with VisionLabs. In November 2017, Sberbank acquired $25.07 \%$ of the Russian company VisionLabs, which is involved in the creation of a facial recognition system [10]. These technologies are now used in the biometric platform that Sberbank is actively developing for identifying customers by face, voice, retina, and other biometric data. The VisionLabs platform is one of the best in the world, both according to international testing data, and according to the results of a large number of internal tests and pilots of Sberbank itself.

\section{Analysis}

1. using regression analysis, we will determine the impact of the selected variables on the profit of Sberbank of Russia and calculate their weight coefficients. The source data is presented in Table 2.

Table 2. Indicators of Sberbank of Russia in the period 2015-2020, billion rubles [11]

\begin{tabular}{|c|c|c|c|c|c|c|}
\hline & $\begin{array}{c}\text { Net } \\
\text { profit }\end{array}$ & $\begin{array}{c}\text { Net \% of } \\
\text { income }\end{array}$ & $\begin{array}{c}\text { Net fee } \\
\text { income }\end{array}$ & $\begin{array}{c}\text { Operating } \\
\text { expenses }\end{array}$ & $\begin{array}{c}\text { Number of } \\
\text { employees, } \\
\text { thousand } \\
\text { people }\end{array}$ & $\begin{array}{c}\text { Number of } \\
\text { offices, } \\
\text { thousand units }\end{array}$ \\
\hline 1 q 2015 & 30,6 & 200,3 & 82,3 & $-139,7$ & 335,00 & 17,10 \\
\hline 2 q 2015 & 54,6 & 227,1 & 87,6 & $-146,6$ & 333,50 & 16,90 \\
\hline 3 q 2015 & 65,1 & 263,4 & 99,2 & $-145,4$ & 331,00 & 16,54 \\
\hline 4 q 2015 & 72,6 & 297,2 & 115,0 & $-191,7$ & 330,70 & 16,40 \\
\hline 1 q 2016 & 117,7 & 325,5 & 94,6 & $-143,8$ & 328,50 & 16,00 \\
\hline 2 q 2016 & 145,4 & 339,3 & 104,7 & $-168,8$ & 326,10 & 15,50 \\
\hline 3 q 2016 & 137,0 & 342,8 & 112,2 & $-163,0$ & 325,20 & 15,30 \\
\hline 4 q 2016 & 141,8 & 355,2 & 124,8 & $-202,0$ & 325,00 & 15,07 \\
\hline 1 q 2017 & 166,6 & 336,6 & 80,4 & $-147,3$ & 321,00 & 14,80 \\
\hline 2 q 2017 & 185,6 & 357,6 & 94,9 & $-161,2$ & 317,80 & 14,50 \\
\hline 3 q 2017 & 224,1 & 375,0 & 100,9 & $-160,4$ & 313,00 & 14,35 \\
\hline 4 q 2017 & 172,4 & 382,9 & 118,0 & $-203,9$ & 310,30 & 14,30 \\
\hline 1 q 2018 & 226,6 & 333,5 & 94,4 & $-146,0$ & 308,56 & 14,25 \\
\hline 2 q 2018 & 200,8 & 349,0 & 113,7 & $-153,4$ & 300,40 & 14,20 \\
\hline 3 q 2018 & 228,1 & 359,3 & 114,6 & $-156,8$ & 296,75 & 14,20 \\
\hline 4 q 2018 & 176,2 & 354,7 & 122,6 & $-208,6$ & 293,80 & 14,19 \\
\hline 1 q 2019 & 226,1 & 337,5 & 102,9 & $-150,7$ & 290,40 & 14,19 \\
\hline 2 q 2019 & 227,0 & 353,0 & 103,0 & $-169,0$ & 289,10 & 14,18 \\
\hline 3 q 2019 & 179,9 & 354,0 & 143,7 & $-166,9$ & 285,10 & 14,17 \\
\hline 4 q 2019 & 212,0 & 371,0 & 148,3 & $-238,0$ & 281,34 & 14,17 \\
\hline 1 q 2020 & 120,5 & 371,9 & 126,4 & $-169,2$ & 279,90 & 13,98 \\
\hline 2 q 2020 & 166,7 & 399,0 & 120,0 & $-172,4$ & 278,50 & 13,74 \\
\hline 3 q 2020 & 271,4 & 411,3 & 147,7 & $-175,5$ & 276,6 & 13,20 \\
\hline
\end{tabular}


The results of regression analysis performed using Microsoft Excel SOFTWARE are shown in Figure 2.

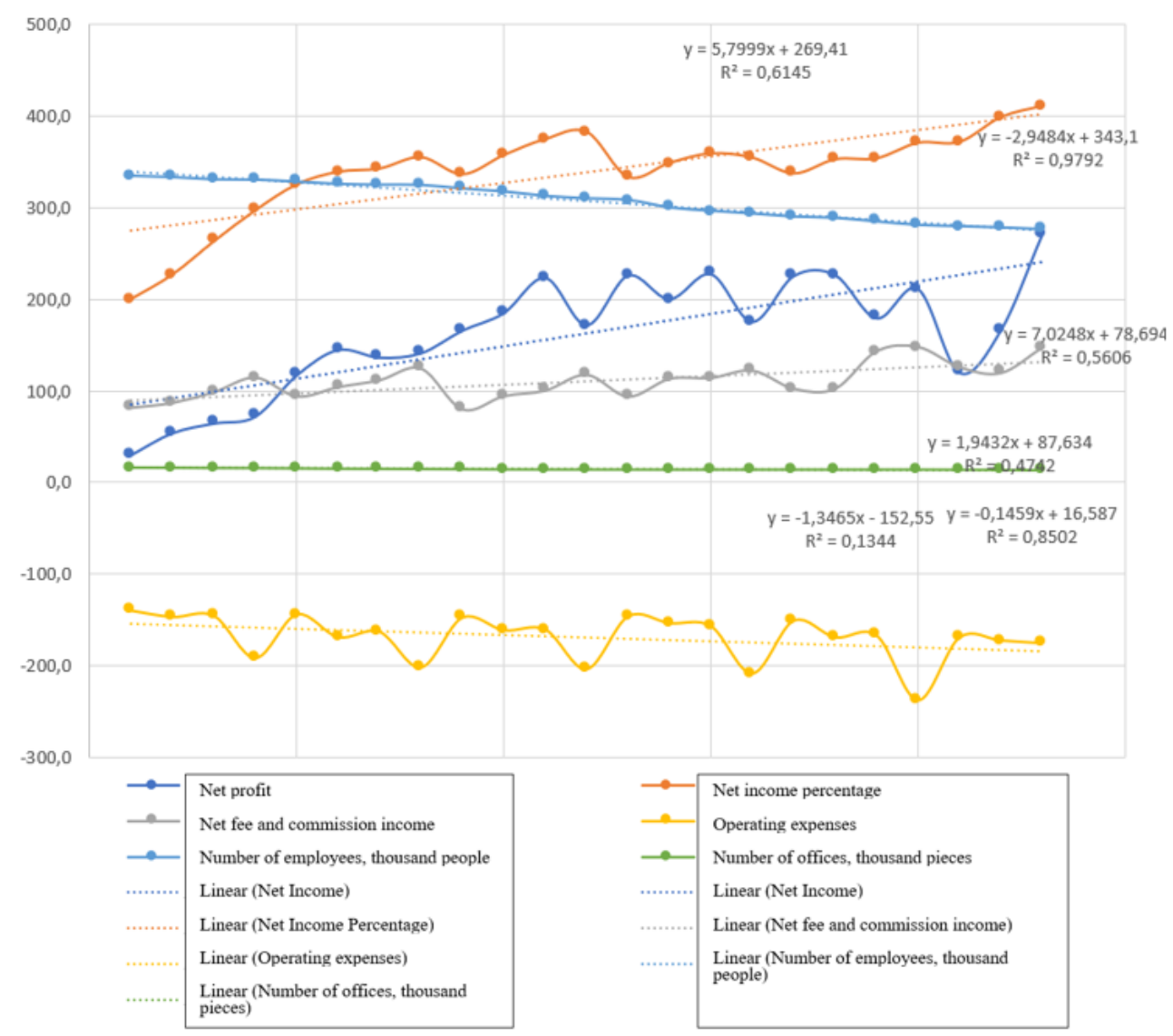

Fig. 1. Dependence of Sberbank of Russia's net profit on various factors

Dependence of Sberbank of Russia's net profit on various factors the regression analysis of changes in profit depending on changes in the selected factors has shown that their influence is significant, which is confirmed by the obtained values of the determination coefficients.

As a result of the regression analysis performed using Excel, the following regression equation was obtained:

$$
\Delta \mathrm{y}=-13,51-0,29 \mathrm{x}_{1}-0,51 \mathrm{x}_{2}-0,19 \mathrm{x}_{3}-1,7 \mathrm{x}_{4}-135,10 \mathrm{x}_{5}
$$

It was found that the change in the Bank's net profit is also affected by other factors not described in the model, this effect is equal to 13.51 billion rubles.

The growth of net interest income for the 3rd quarter of 2020 amounted to 12.3 billion rubles, net Commission income-27.7 billion rubles, and the reduction in operating expenses reached 3.1 billion rubles, the reduction in the number of employees and the number of offices amounted to 1.9 thousand people and 0.5 thousand units, respectively. The change in net profit due to these factors alone was: $\Delta y=58.54$ billion rubles, which is $56 \%$ of the change in Sberbank's net profit in the amount of 104.7 billion rubles. Consequently, for the 3rd quarter of 2020, 58.54 billion rubles. the reason for the increase in net profit is due to the introduction of digital transformation for the Bank's clients. 
2. correlation analysis was used to assess the impact of the introduction of the Sberbank Online mobile app on a number of interrelated performance indicators of Sberbank of Russia. The results of correlation analysis based on data for 2015-2019 are presented in Table 3 .

Table 3. Correlation analysis of indicators of "Sberbank of Russia»

\begin{tabular}{|c|c|c|c|c|c|c|c|c|}
\hline & 运 & 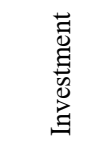 & $\sum_{i=1}^{n} \cdot \sum_{0}^{0}$ & 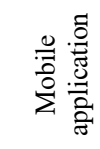 & 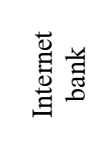 & 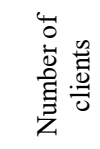 & 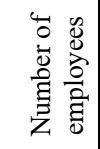 & 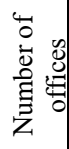 \\
\hline Profit & 1 & & & & & & & \\
\hline Investment & 0,7610 & 1 & & & & & & \\
\hline SMS service & $-0,2618$ & $-0,0194$ & 1 & & & & & \\
\hline Mobile application & 0,7718 & 0,9111 & $-0,2721$ & 1 & & & & \\
\hline Internet bank & 0,7641 & 0,9912 & $-0,0201$ & 0,9327 & 1 & & & \\
\hline Number of clients & 0,7611 & 0,9629 & $-0,0429$ & 0,9579 & 0,9867 & 1 & & \\
\hline $\begin{array}{l}\text { Number of } \\
\text { employees }\end{array}$ & $-0,7725$ & $-0,8823$ & 0,3747 & $-0,9855$ & $-0,8921$ & $-0,9101$ & 1 & \\
\hline Number of offices & $-0,7501$ & $-0,9868$ & $-0,0085$ & $-0,9210$ & $-0,9972$ & $-0,9875$ & 0,8767 & 1 \\
\hline
\end{tabular}

As you can see from the correlation analysis, the relationship between such indicators as profit and investment in financial and technological services can be considered high, since it is in the range between 0.7 and 0.9 . This means that by developing investment activities in the direction of modern technologies, the Bank offers its clients a new level of services, thereby increasing its attractiveness, as well as the possibility of obtaining more profit.

There is also a high correlation between profit and such indicators as the number of users of the Sberbank Online mobile app and the number of Internet banking users (correlation coefficients of 0.77 and 0.76 , respectively). Based on these results, it can be concluded that customers who use these software products have an impact on Sberbank's profit, since these users make up approximately $66 \%$ of all Sberbank customers. Accordingly, there is also a high correlation between the number of customers in General and profit, equal to 0.76. As for the SMS service "Mobile Bank", the connection is negative, but does not significantly affect the net profit. This is due to the transition of all received services to a digital platform, but this service will not disappear completely, since users of this service are usually middle-aged people and above who use mobile devices that do not support the Sberbank Online app, or customers do not need to learn new technologies due to the simplicity of the requested operations.

During the study period, there is also a tendency to reduce the number of Sberbank employees and service offices. This is due to the fact that most of the work is done with machinery. There is a very high correlation between investment in FINTECH and the number of users of the mobile app. During the analyzed period, investments in the financial and technological sector increased significantly. Sberbank is constantly looking for new companies to conduct either joint activities or complete takeover of a FINTECH company. Thus, thanks to investments in FINTECH, the functionality of the application increases and the range of products and services that the user can get without visiting the Bank expands, thereby increasing the number of new users and customers.

There is also a high negative correlation $(-0.99)$ between the number of offices and the number of Internet banking users, which indicates an inverse relationship between the indicators. In other words, as users of the Sberbank desktop version increase, the number of 
service offices decreases, which is logical and confirmed in practice. Users prefer not to spend time on basic operations (money transfer, payment of utilities, receipt of a current account and various certificates), but to perform them independently. However, complex requests, such as obtaining a loan, especially for legal entities, are usually impossible without visiting Sberbank and providing documentation, as well as signing a contract.

Thus, the results of the correlation analysis show an increase in the number of users of the Sberbank Online mobile app, an increase in the company's profit, and a reduction in employees and service offices.

3. the next stage of the research was to analyze the results of Sberbank's transaction to purchase $25.07 \%$ of shares in the high-tech company VisionLabs as part of the formation of a client-centric approach to the formation of the ecosystem of Sberbank of Russia based on the accumulated excess yield (CAR) method.

The transaction took place on November 17, 2017, and before that, information about the Bank's intentions was not published in the public domain. Calculate the daily return on shares of Sberbank of Russia and the IMOEX index based on data from the Moscow exchange [12]. The results are presented in Table 4.

Table 4. Daily returns on the observation window $(-3 ; 0)$ и $(+1 ;+2)$

\begin{tabular}{|c|c|c|c|c|c|c|}
\hline & -3 & -2 & -1 & 0 & 1 & 2 \\
\hline Vision Labs & 2,21 & 2,06 & 0,69 & $-0,81$ & - & - \\
\hline IMOEX & $-0,04$ & $-1,62$ & 0,04 & $-0,03$ & - & - \\
\hline & 3 & 4 & 5 & 6 & 7 & \\
\hline Vision Labs & - & 2,85 & $-0,32$ & $-2,04$ & 1,08 & \\
\hline IMOEX & - & 1,19 & 0,20 & $-0,54$ & 0,59 & \\
\hline
\end{tabular}

Next, we calculate the excess return on shares of Sberbank of Russia for each day of observation (Table 5).

Table 5. Excess return on shares of Sberbank of Russia»

\begin{tabular}{|c|c|c|c|c|c|c|}
\hline & -3 & -2 & -1 & 0 & 1 & 2 \\
\hline Vision Labs & 2,25 & 3,67 & 0,64 & $-0,78$ & - & - \\
\hline & 3 & 4 & 5 & 6 & 7 & \\
\hline Vision Labs & - & 1,66 & $-0,53$ & $-1,50$ & 0,49 & \\
\hline
\end{tabular}

We calculate the accumulated excess yield over the observation period, which acts as a criterion for the effectiveness of the transaction. It is made up of 5.91. Thus, the market positively assessed the expansion of the Sberbank ecosystem for consumers. In March 2019, at the competition within the international conference on computer vision CVPR2019, VisionLabs presented Liveness technology, which exceeded the results of the secondplace participant by 1.5 times. At the end of 2019, the Visionlabs algorithm was among the top three in the world testing of facial recognition algorithms by the US National Institute of standards and technology (NIST) [8]. Thus, Sberbank's ecosystem now includes the world's best innovative company, which proves the correctness of the strategic and investment decision to buy part of this company [11]. It should also be noted that Sberbank's annual report for 2019 actively uses the survey method to assess the effectiveness of digital transformation. The results of the surveys and the results obtained in this study also allow us to indirectly verify the correctness of the conclusions made.

\section{Conclusions}

Sberbank of Russia is at the stage of digital transformation, which is associated with the 
formation of a client-centric ecosystem. Sberbank offers its customers convenient digital services based on platform and cloud technologies. The correlation and regression analysis of Sberbank of Russia's activities and the accumulated excess profitability analysis allow us to conclude that digitalization has a positive impact on the company's economic results: the number of customers is growing, the range of non-financial services in the group of companies is expanding, and financial savings are being observed due to the reduction of offices and employees who performed banking operations in the traditional business model of banks.

Changes in the Bank's net profit are influenced by the following factors: net interest income, net Commission income, operating expenses, number of employees and offices, as well as other factors not described in the model. The correlation analysis showed that the relationship between such indicators as profit and investment in financial and technological services can be considered high. There is a high correlation between the profit and the number of users of the Sberbank Online mobile app and the number of Internet banking users. There is a high negative correlation between the number of offices and the number of Internet banking users. As a result of the analysis of the profitability of Sberbank of Russia PJSC based on the accumulated excess profitability method, it can be concluded that the market positively assessed the expansion of the Sberbank ecosystem for consumers.

\section{References}

1. V.D. Markova, Ecotrends, 12, 14 (2018)

2. Global FinTech Adoption Index, 44 (2019)

3. B. King, Bank 4.0: banking everywhere, never at bank, 347 (2018)

4. U.M. Akatkin, O.E. Karpov, V.A. Konyavsky, E.D. Yasinovskaya, Business Informatics, 4, 12 (2017)

5. L.V. Koh, U.V. Koh, Bulletin of the Trans-Baikal State University, 6, 11 (2019)

6. Ecosystem of Sberbank (2020) https://www.sberbank.com/ru/eco

7. Development of Sberbank's Non-banking Services Ecosystem, Tadviser (2020)

8. Report of Sberbank of Russia, 300 (2019)

9. Sberbank online (2020) https://bankspec.ru/

10. A. Frolov, VisionLabs (2017) https://vc.ru/

11. Sberbank (2020) https://www.sberbank.com

12. Moscow exchange (2020) https://www.moex.com/ 